\title{
AN INVESTIGATIONAL RESEARCH ON THE CORRELATION BETWEEN THE MANAGER'S ROLE IN TRAINING PROGRAMS AND TRAINING TRANSFER IN A LOCAL GOVERNMENT OFFICE IN MALAYSIA
}

\author{
Ismail Azman ${ }^{1}$ \\ Hamid Norashikin Sahol ${ }^{2}$ \\ Hua Ng Kueh ${ }^{3}$ \\ Ali Fazilatulaili ${ }^{4}$
}

\begin{abstract}
This research was designed to investigate the correlation between manager's role and training transfer. A survey method was employed to gather 427 usable questionnaires from government servants in a local government office in Malaysia. The outcome of stepwise regression study showed four important findings: firstly, support is insignificantly correlated with training transfer. Secondly, communication is significantly correlated with training transfer. Thirdly, assignment is insignificantly correlated with training transfer. Fourthly, delivery mode is significantly correlated with training transfer. The statistical value of this research shows that communication and delivery mode have played important roles as determinants of training transfer, but support and assignment have not played important roles as determinants of training transfer in the organizational sample. In this paper, discussions, propositions and conclusions are elaborated.
\end{abstract}

Key Words: Manager's role, training transfer, local government office in Malaysia

JEL codes:M12

\section{Introduction}

Managers plays a significant role between the linkage in top management or employers and subordinates where managers are those responsible in making sure the execution of job is done accurately where they are also often given key tasks and responsibilities to lead the development of work teams (Abdullah et al., 2011; Goldstein and Ford, 2002; Ismail et al., 2010a, 2010b, 2011a; Noe 2008). Managers' also has the contractual obligation to work with their employers to design, implement and monitor the organizational policies, procedures and plans, including training programs (Ellinger et al., 2005; Ismail et al., 2009, 2010a, 2010b, 2011a; Robbins and DeCenzo, 2004). In organizations, the role of managers is viewed in the administrative angle and perspective. From the customary administrative perspective, managers hold the main task in identifying the daily, customary and short-term employee incompetency, as well as to report such incompetency to the top management and employers who will then design and conduct training programs as a

\footnotetext{
${ }^{1}$ National Defence University of Malaysia, Faculty of Defence \& Management Studies, Sungai Besi Camp. 57000 Kuala Lumpur, Malaysia,e-mail:azisma08@gmail.com

${ }^{2}$ National Defence University of Malaysia, Faculty of Defence \& Management Studies, Sungai Besi Camp. 57000 Kuala Lumpur, Malaysia, e-mail: platino_love@yahoo.com.sg

${ }^{3}$ Universiti Malaysia Sarawak, Faculty of Cognitive Science \& Human Development, 94000 Kota Samarahan. Sarawak, Malaysia, e-mail: ahua_101@yahoo.com

${ }^{4}$ National Defence University of Malaysia, Center for Defence Foundation Studies, Sungai Besi Camp. 57000 Kuala Lumpur. Malaysia, e-mail:fazilatulaili@upnm.edu.my
} 
solution towards such employee incompetency (Abdullah et al., 2011; Ismail et al., 2007, 2009; 2010a, 2010b, 2011a; Rodrígues and Gregory, 2005).

In an era of globalization, many organizations have remodeled their paradigms from traditional job-based training to achieve organizational strategy and goals (Abdullah et al., 2011; Ellinger et al., 2005; Ismail et al., 2007, 2009, 2010a, 2010b, 2011a; MacNeil, 2004). Under this approach, a training program is viewed as a strategic function of human capital management, where managers are highly empowered by the employer to effectively design and administer training programs, develop useful competencies not only to overcome daily problems, but to also support the development and future growth of the organization (Abdullah et al., 2011; DeSimone et al., 2002; Ismail et al., 2009, 2010a, 2010b, 2011a; MacNeil, 2004).

In the design stage of training programs, managers often collaborate with top management or employers and senior employees in conducting training needs analysis, establishing course objectives, developing effective lesson plans, selecting program methods and techniques, and prepare course materials (Goldstein and \& Ford, 2002; Ismail et al., 2009, 2010a, 2010b, 2011a; Nijman, 2004). In the process of administering the training programs, managers usually refer to the top management team and experienced employees to ensure that the implementation of training activities accomplishes the set objectives (Abdullah et al., 2011; DeSimone et al., 2002; Ismail et al., 2010a, 2010b, 2011a; Yamnill and McLean, 2001). For example, the role of managers in managing training programs is not just restricted at bestowing the financial and physical facility support, but they should also have the competency to establish realistic and achievable learning expectations, provide encouragements and positive reinforcements, create a constructive impetus for the training program, generate interest in the employees to attend training programs for the purpose of improving and developing their competencies (Blanchard and Thacker, 2007; Chang, 2002; Golemen, 2000; Ismail et al.,2009, 2010a, 2010b, 2011a).

In organizational context, the managers play critical role in providing encouragement or otherwise to their subordinates to join and take part in training programs (Abdullah et al., 2011; Blanchard and Thackers, 2007; Ismail et al., 2009, 2010a, 2010b, 2011a; Noe, 2008). Many scholars have identifed that manager's role in training programs consist of four prominent features: support, communication, assignments and delivery mode are four prominent features of a manager's role that can affect the overall success of training programs (Chiaburu and Tekleab, 2005; Ismail et al., 2007, 2010a, 2010b, 2011a). Surprisingly, extant studies in the workplace training highlight that the ability of managers to properly implement such managers role features may lead to an increased training transfer in organizations (Chiaburu and Takleab, 2005; Nijman, 2004; Tai 2006).

Although numerous studies have been done, the role of manager's role as an important predicting variable is less stressed in training program research literature (Abdullah et al., 2011; Chiaburu and Takleab, 2005; Dawley et al., 2008; Ismail et al., 2007, 2010a, 2010b, 2011a; Saks and Belcourt, 2006 ). Many scholars reveal that the role of manager's role as a predicting variable is given less stress in earlier studies because it has much explained the managers role characteristics and agreed little notice on how and why the elements of manager's role influencing training transfer in the workplace training program models. As an outcome, findings of such studies have not presented satisfactory substantiation to be used as strategy by practitioners to design appropriate strategies and plan for improving the efficacy of employee training and development program in agile organizations (Abdullah et al., 2011; Ismail et al., 2007, 2009, 2010a, 2010b, 2011a; Vuuren et al., 2007). Hence, it supports the researchers to further investigate the nature of this correlation.

\section{Objective of the Study}

This research has four major aims: firstly, it is to measure the relationship between support and training transfer. Secondly, is to measure the relationship between communication and training transfer. Thirdly, is to measure the relationship between assignments and training transfer. Finally, is to measure the relationship between delivery mode and training transfer. 


\section{Explanation of the Constructs}

This study addresses five important variables: support, communication, assignments, delivery mode and training transfer. Firstly, support is frequently defined as managers giving the encouragement to the employees to undergo training programs, assisting them throughout, in terms of time, budget and resources, getting them involved in managerial aspects like decision-making, and guiding them in applying the newly acquired competencies (Abdullah et al., 2011; Chiaburu and Tekleab, 2005; Ismail et al., 2007, 2010a, 2010b, 2011a). Secondly, communication is generally seen as managers delivering information on procedures, contents, responsibilities and objectives of the training program, and conducting discussions on how best to perform certain tasks and the related necessary skills required, explaining the benefits of attending training programs and providing performance feedback (Abdullah et al., 2011; Ismail et al., 2007, 2010a, 2010b, 2011a; McShane and Von Glinow, 2005; Vuuren et al., 2007).

Thirdly, assignments is referred to where managers give voluntary decisions (employees are given choices) or mandatory decision (employees are given alternatives) in assigning employees to attend training programs (Machin and Treloar, 2004; Saks and Belcourt, 2006). Fourthly, delivery mode is frequently viewed as the method of training being performed during training programs such as trainer's preference in conducting the program based on the training objectives, the types of trainees and the training environment (Desimone et al., 2002; Klein et al., 2006 ). Finally, training transfer has two major types: direct transfer and indirect transfer. Direct transfer is often related to as the ability of trainees to learn and implement the knowledge, skills, and abilities gained from training programs to similar situations (i.e., at training place). While, indirect transfer is often seen as the ability of trainees to learn and implement the knowledge, skills, and abilities gained from training programs to dissimilar situations (i.e. at the workplace). Both training transfers may inspire trainees to improve daily tasks, amplify professional development and meet organizational needs and expectations (Abdullah et al., 2011; Acton and Golden, 2003; Goldstein and Ford, 2002; Ismail et al., 2010a, 2010b, 2011a; Sisson, 2001).

In a training model, many academicians and researchers view that support, communication, assignments, delivery mode and training transfer are of different paradigms, but greatly interrelated. For example, the ability of managers to adequately provide material and moral supports, openly communicate the advantages and magnitude of training programs, clearly deliver assignments to employees and appropriately plan delivery mode may lead to an increased training transfer in organizations (Abdullah et al., 2011; Dawley et al., 2008; Ismail et al., 2007, 2010a, 2010b, 2011a; Noe and Wang, 2006; Saks and Belcourt, 2006).

\section{Literature Review}

\section{Relationship between Support and Training Transfer}

Several studies about training support were conducted based on different samples. These studies were the 119 employees who attended training program in a large organization in USA (Chiaburu and Takleab, 2005), 600 adult students enrolled in training courses in a large university located in Midwestern United States (Klein et al., 2006), and 346 employees from a manufacturing facility in US (Dawley, Andrews and Bucklew, 2008). These studies advocated that the ability of supervisors to adequately provide training supports had increased training transfer in the respective organizations (Chiaburu and Takleab, 2005; Dawley et al., 2008).

\section{Relationship between Communication and Training Transfer}

Few studies about training communication were done using different samples. These studies were 10 human resources practitioners in performance improvement technology training program in Korea (Lim and Johnson, 2002), 456 employees in telecommunication services in Dutch (Vuuren et al., 2007), and 195 employees in a local government office in Malaysia (Ismail et al., 2007) are such examples. These studies supported that the aptitude of managers to use communication openness 
about the training programs (e.g., feedback and discussion) had enhanced training transfer in the organizations (Ismail et al., 2007; Lim and Johnson, 2002; Vuuren et al., 2007).

\section{Relationship between Assignments and Training Transfer}

Certain studies about training assignments were conducted based on different samples. These studies were 184 employees belonging to 18 banks in Northern Taiwan (Tsai and Tai, 2002), and 150 members of a large training and development society in Canada (Saks and Belcourt, 2006). These studies found that the aptitude of managers to properly deliver voluntary and mandatory assignments had increased training transfer in the organizations (Saks and Belcourt, 2006; Tsai and Tai, 2002).

\section{Relationship between Delivery Mode and Training Transfer}

Not many studies about training delivery mode were done using different samples but the studies conducted were the 200 employees across 39 software companies in Ireland (Acton and Golden, 2003), and 600 students who enrolled in classroom and blended learning courses (Klein et al., 2006). These studies reported that the aptitude of supervisors to appropriately select and recommend delivery mode had increased training transfer in the organizations (Acton and Golden, 2003; Klein et al., 2006).

The investigation and analysis is consistent with the notion of organizational behavior theory. For example, Adams' $(1963 ; 1965)$ equity theory states that fair or unfair treatment has a significant impact on individual attitudes and behavior. Besides that, Vrooms' (1964, 1973) expectancy theory highlights that an individual will perform certain actions if he/she perceives such actions may bring valued outcomes. Thus, Locke and Latham's (1990) goal setting theory postulates that goals direct individuals to perform a task. The application of these theories in a training model shows that the fair treatments, valued outcomes and clarity of goals will be achieved if managers may adequately provide support to employees who attend training programs, openly communicate the information about training programs, clearly deliver assignments about training programs and appropriately plan delivery mode in training programs. As a result, it may motivate trainees to an enhanced training transfer in organizations (Abdullah et al., 2011; Dawley et al., 2008; Ismail et al., 2007, 2010a, 2010b, 2011; Noe and Wang, 2006; Saks and Belcourt, 2006).

\section{Conceptual Framework and Research Hypothesis}

The literature has been used as foundation of developing a conceptual framework for this study as shown in Figure 1.

\begin{tabular}{|l|l|}
\multicolumn{1}{l|}{ Independent Variable } & Dependent Variable \\
\hline Manager's Role in Training Programs: \\
- Support \\
- Communication \\
- Assignment \\
- Delivery Mode
\end{tabular}

\section{Figure no. 1: Conceptual Framework}

Based on the framework, it was hypothesized that:

H1: There is a positive relationship between support and training transfer

$\mathrm{H} 2$ : There is a positive relationship between communication and training transfer

H3: There is a positive relationship between assignments and training transfer

H4: There is a positive relationship between delivery mode and training transfer

\section{Methodology}

\section{Research Design}

This research uses a cross-sectional research design, which allows the researchers to amalgamate training management literature, the in-depth interview, the pilot study and the actual 
survey as the main procedure to gather data for this study. The use of such methods may improve the inadequacy of single method and increase the ability to gather accurate and less biased data (Abdullah et al., 2011; Ismail et al., 2010a, 2010b, 2011a, 2011b; Sekaran, 2000). This study was conducted in a local government office in Malaysia. These organizations have designed human capital development programs and given autonomous power to managers to closely monitor the implementation of the pograms in order to achieve their visions as the prime mover in developing their areas. At the initial stage of the study, in-depth interviews were conducted involving six senior officers, namely the Head of Human Resource Management Unit (20 years of experience), the Head of Town Planning Unit (14 years of experience), training instructor from the Enforcement Unit (20 years of experience), Senior Engineer from the Project Engineering Unit (17 years of experience), Assistant of Accountant from the Finance Unit (9 years of experience), and Assistant of Administrative Officer from Human Resource Development Unit (17 years of experience).

They were selected using a purposive sampling where the employees have good knowledge and experience about the design and administration of training programs. Information gathered from such employees helped the researchers to understand the characteristics of manager's role in training programs, and training transfer features, as well as the relationship between such variables in the studied organizations. After that, the information was compared with the related literature review and the results of this comparison were used as a guideline to develop the content and format of the survey questionnaire for the pilot study. Next, a pilot study was conducted by distributing 60 survey questionnaires to employees from administrative divisions and technical divisions through contact persons (i.e., HR manager, secretary of HR manager, secretary of department heads and supervisors) in order to verify the content and format of the questionnaire for the actual study. The results of pilot study showed that the variables had exceeded the value of 0.70 , indicating that they met the adequate standards of reliability analysis (Fraenkel and Wallen, 2006; Kline, 2000). Hence, the back translation technique was used to translate the survey questionnaires in Malay and English; this would augment the validity and reliability of the instrument (Abdullah et al., 2011; Kothari, 2008; Ismail et al., 2010a, 2010b, 2011).

\section{Measures}

The survey questionnaire consists of four sections. First, support was measured using three items that were modified from the training support literature (Abdullah et al., 2011; Ayres, 2005; Chiaburu and Tekleab, 2005; Guerrero and Sire, 2001; Holton et al., 2000; Ismail et al., 2009, 2010a, 2010b, 2011a). Second, communication was measured using six items that were modified from the training transfer literature (Abdullah et al., 2011; Ismail and Bonggogoh, 2007; Ismail et al., 2009, 2010a, 2010b,2011; Tsai and Tai, 2003). Third, assignments were measured using seven items that were modified from the training assignment literature (Chang, 2002; Guerrero and Sire, 2001). Fourth, delivery mode was measured using six items taken from training delivery literature (Acton and Golden, 2003; Klein et al., 2006). Finally, training transfer was measured using five items taken from training transfer literature (Chiaburu and Tekleab, 2005; Ismail and Bonggogoh, 2007; Ismail et al., 2009, 2010b). All the items used in the questionnaire were measured using a 7item scale ranging from 'strongly disagree' (1) to 'strongly agree' (7). Demographic variables were used as the controlling variable because this study focused on employees' attitude.

\section{Unit of Analysis and Sampling}

The researchers had obtained an official approval to conduct the study from the heads of the studied organizations and also received advice from them about the procedures of conducting the survey in their organizations. The targeted population for this study was employees who worked in the organizations. After considering the organizational rules, a convenience sampling technique was used to distribute 700 survey questionnaires to all participants through the Human Resource Management Units in the organizations. Of the total number, 427 usable questionnaires were 
returned to the researchers, yielding a response rate of 61 percent. The survey questionnaires were answered by participants based on their consent and voluntary basis. The number of this sample exceeded the minimum sample of 30 participants as required by probability sampling technique, showing that it may be analyzed using inferential statistics (Ismail et al., 2010a, 2010b, 2011; Leedy and Ormrod, 2005; Sekaran, 2000;).

\section{Data Analysis}

The Statistical Package for Social Science (SPSS) version 16.0 was used to analyse the data from the questionnaires. Firstly, exploratory factor analysis (EFA) was used to assess the validity and reliability of measurement scales (Hair et al, 1998; Nunally and Bernstein, 1994). Secondly, analysis of variance, Pearson correlation analysis and descriptive statistics were conducted to analyze the constructs and the usefulness of the data set (Tabachnick et al., 2001; Yaacob, 2008). Finally, Stepwise Regression analysis was undertaken to assess the magnitude of each independent variable, the relationship between many independent variables, one dependent variable, the contribution and influence of each independent variable on dependent variable (Baron and Kenny, 1986; Foster et al., 1998; Wong et al., 1995). In this regression analysis, standardized coefficients (Standardized Beta) were used for all analyses (Jaccard et al., 1990).

\section{Findings}

\section{Participant Characteristics}

Table 1 shows that most of the participant characteristics were males (53.6\%), age 46 years old and above (40.9\%), non-management workers (56.4\%), degree holders $(39.1 \%)$, and workers who have been employed for more than 21 years $(37.3 \%)$.

\section{Participant Characteristic $(\mathrm{N}=427)$}

\begin{tabular}{|l|l|}
\hline Gender $(\%)$ & Education $(\%)$ \\
Male $=53.6$ & Degree $=39.1$ \\
Female $=46.4$ & Diploma $=12.7$ \\
& STPM $=5.5$ \\
$\underline{\text { Age }(\%)}$ & SPM $=32.7$ \\
$18-25=5.5$ & Competency Certificates $=10.0$ \\
$26-35=29.1$ & \\
$36-46=24.5$ & Length of Service $(\%)$ \\
$>46=40.9$ & $<1$ years $=1.8$ \\
& $1-5$ years $=12.7$ \\
$\underline{\text { Position }(\%)}$ & 6-10 years $=17.3$ \\
Management $=43.6$ & $11-15$ years $=20.0$ \\
Non-management $=56.4$ & $16-20$ years $=10.9$ \\
& $>21$ years $=37.3$ \\
\hline
\end{tabular}

Note:

SPM-Sijil Pelajaran Malaysia/Malaysian Certificate of Education

STPM-Sijil Tinggi Pelajaran Malaysia / Higher School Certificate

\section{Validity and Reliability Analyses for the Measurement}

Table 2 shows the validity and reliability of the measurement scales. The survey questionnaires comprises 27 items, which related to five variables: support (3 items), communication (6 items), delivery mode (6 items), assignment ( 7 items), and training transfer (5 items). Relying on Hair et al. (1998) and Nunally and Bernstein (1994)'s guideline, these statistical analyses showed that: (1) all research variables exceeded the acceptable standard of Kaiser-MeyerOlkin's value of 0.6, (2) all research variables were significant in Bartlett's test of sphericity, (3) all research variables had eigenvalues larger than 1, and (4) the items for each research variable 
exceeded factor loadings of 0.50 (Hair et al., 1998). Besides that, all research variables exceeded the acceptable standard of reliability analysis of 0.70 (Nunally and Bernstein, 1994). These statistical analyses confirm that the measurement scales met the acceptable standards of validity and reliability analyses as shown in Table 2 .

The Results of Validity and Reliability of the Measurement Scales

\begin{tabular}{lccccccc}
\hline Measure & $\begin{array}{c}\text { No. } \\
\text { of } \\
\text { Items }\end{array}$ & $\begin{array}{c}\text { Factor } \\
\text { Loadings }\end{array}$ & KMO & $\begin{array}{c}\text { Bartlett's } \\
\text { Test of } \\
\text { Sphericity }\end{array}$ & Eigenvalue & Variance Explained & $\begin{array}{c}\text { Cronach } \\
\text { Alpha }\end{array}$ \\
\hline Support & 3 & $55-75$ & 73 & 584.21 & 2.34 & 77.97 & 86 \\
Communication & 6 & $51-87$ & 88 & 2.303 & 4.53 & 75.55 & 93 \\
Assignment & 7 & $55-90$ & 89 & 2.571 & 5.01 & 71.51 & 93 \\
Delivery Mode & 6 & $57-89$ & 90 & 2.689 & 4.83 & 34 & 95 \\
Training Transfer & 5 & $82-90$ & 87 & 1.639 & 3.84 & 76.87 & 92 \\
\hline
\end{tabular}

\section{Analysis of the Constructs}

Table 3 shows the results of Pearson correlation analysis and descriptive statistics. The mean values for the variables are from 5.0 to 6.0, signifying that the levels of support, communication, assignments, delivery mode and training transfer ranging from high (4) to highest level (7). The correlation coefficients for the relationship between the independent variable (support, communication and delivery mode) and the mediating variable (motivation to learn) and the dependent variable (training transfer) were less than 0.90 , indicating that the data were not affected by serious collinearity problem (Hair, et al., 1998).

Pearson Correlation Analysis and Descriptive Statistics

\begin{tabular}{|l|c|c|c|c|c|c|c|}
\hline Variable & Mean & \multirow{2}{*}{$\begin{array}{l}\text { Standard } \\
\text { Deviation }\end{array}$} & & \multicolumn{5}{|c|}{ Pearson Correlation Analysis } \\
\cline { 4 - 8 } & & & 1 & 2 & 3 & 4 & 5 \\
\hline 1. Support & 5.0 & 1.26 & 1 & & & & \\
\hline 2. Communication & 5.0 & 1.22 & $.755^{* *}$ & 1 & & & \\
\hline 3. Assignments & 5.0 & 1.31 & $.649^{* *}$ & $.732^{* *}$ & 1 & & \\
\hline 4. Delivery Mode & 5.0 & 1.18 & $.668^{* *}$ & $.790^{* * *}$ & $.766^{* * *}$ & 1 & \\
\hline 5. Training Transfer & 6.0 & 0.86 & $.383^{* *}$ & $.477^{* *}$ & $.402^{* *}$ & $.467^{* *}$ & 1 \\
\hline
\end{tabular}

Note: Significant at $* \mathrm{p}<0.05 ; * * \mathrm{p}<0.01 ; * * \mathrm{p}<0.000$

\section{Outcomes of Testing Hypotheses 1 and 2}

Table 4 shows that demographic variables were entered in Step 1 and then followed by entering independent variable (i.e., support, communication, assignments and delivery mode) in Step 2. Training transfer was used as the dependent variable. An examination of multicollinearity in the regression analysis shows that the tolerance values for the relationships between training assignment (i.e., support, communication, assignment and delivery mode) and training motivation were $0.93,0.93,0.95$ and 0.94 , respectively. These tolerance values were more than tolerance value of 0.20 (as a rule of thumb), indicating the variables were not affected by multicollinearity problem (Fox, 1991; Tabachnick and Fidell, 2001). 
Results of the Stepwise Regression Analysis

\begin{tabular}{|l|c|c|}
\hline \multirow{2}{*}{ Variable } & \multicolumn{2}{|c|}{$\begin{array}{c}\text { Dependent Variable } \\
\text { (Training Transfer) }\end{array}$} \\
\cline { 2 - 3 } & Step 1 & Step 2 \\
\hline Control Variables & -0.05 & -0.04 \\
Gender & -0.03 & -0.01 \\
Position & 0.14 & 0.09 \\
Age & -0.08 & 0.03 \\
Education Level & -0.10 & -0.04 \\
Length of Service & & \\
Independent Variables & & $\mathbf{0 . 0 2}$ \\
Support & & $\mathbf{0 . 2 5}^{* *}$ \\
Communication & & $\mathbf{0 . 0 3}$ \\
Assignments & 0.03 & $\mathbf{0 . 2 4}$ \\
Delivery mode & 0.01 & 0.26 \\
\hline$R^{2}$ & 0.03 & 0.24 \\
Adjusted R & 1.50 & 0.23 \\
$\mathrm{R}^{2}$ Change & 1.50 & $11.25^{* * * *}$ \\
F & & $32.19^{* * * *}$ \\
F Change $\mathrm{R}^{2}$ & & \\
\hline
\end{tabular}

Note: Significant at $* \mathrm{p}<0.05, * *<0.01, * * * \mathrm{p}<0.000$

Table 4 shows the results of hypothesis testing were shown in the Step 2. Firstly, support insignificantly correlated with training transfer $(\beta=0.02, \mathrm{p}>0.05)$, therefore H1 was not supported. Secondly, communication significantly correlated with training transfer $(B=0.25, \mathrm{p}<0.01)$, therefore $\mathrm{H} 2$ was supported. Thirdly, assignment insignificantly correlated with training transfer $(\beta=0.03$, p>0.05), therefore H3 was not supported. Fourthly, delivery mode significantly correlated with training transfer $(\beta=0.24, \mathrm{p}<0.01)$, therefore $\mathrm{H} 4$ was supported. The inclusion of these variables in Step 2 has explained 26 percent of the variance in the dependent variable. This result sends a message that communication and delivery mode act as important determinants of training transfer, but support and assignment do not act as important determinants of training transfer in the studied organization.

\section{Discussion and Implications}

The conclusion of this investigation show that communication and delivery mode have been important determinants of training transfer in the organizational sample. In the studied organization, managers have provided adequate support (e.g., encourage employees to attend training programs and apply newly acquired knowledge and skills that they gain from training programs in their jobs), make use of comfortable communication practice (e.g., provide feedback, support discussion and openly deliver information on training) and chosen the appropriate delivery mode (e.g., classroom and computers) when dealing with training programs. The majority of the employees perceive that the ability of managers to properly implement comfortable communication style and plan appropriate delivery mode had increased training transfer in the organization.

This investigation provides momentous impacts on three major aspects: theoretical contribution, robustness of research methodology, and contribution to the human resource development practitioners. In terms of theoretical contribution, this investigation and research revealed two important results. First, communication and delivery mode have been important determinants of training transfer. This finding is consistent with the studies by Ismail et al., 2007, 2010a and 2010b; Lim and Johnson, 2002; Vuuren et al 2007. Second, support and assignment have not been important determinants of training transfer. This finding is not consistent with the studies by Chaiburu and Takleab, 2005; Dawley et al., 2008. A thorough review of the in-depth interview 
results shows that this finding may be affected by peripheral reasoning. Firstly, the respondents of this study have different needs and expectations about their manager's styles. In this situation, the respondents may have different attitudes and values in appreciating and accepting the manager's styles in providing support and giving assignments about the training programs. Secondly, the managers in the studied organizations have different capabilities and traits in managing training programs. In this condition, different manager styles in providing support and giving assignments regarding training programs may not be positively recognized and accepted by majority employees.

With respect to the robustness of the research methodology, the survey questionnaires used in this investigation have adequately met the standards of validity and reliability analyses. Hence, this may lead to the production of accurate and reliable findings.

Regarding practical contribution, the findings of this study may be used as important guidelines by top management and employers to improve training and development program in organizations. In order to achieve such objectives, employers and top management need to consider the following suggestions: firstly, update leadership training content and methods according to current organizational changes. Secondly, employee recruitment policy needs to give priority in hiring candidates who have good academics qualifications, knowledgeable and experiences than fresh graduates to fulfil critical positions in organizations. Thirdly, promote pay systems that provide higher rewards to employees who can successfully transfer what they learn from training programs onto the workplace. If these suggestions are properly considered this may lead to an enhanced positive subsequent personal outcomes (e.g., satisfaction, commitment, performance and positive behaviour) in organizations.

\section{Conclusion}

This investigation proposed a conceptual framework based on the workplace training literature. The measurement scales used in this study met the acceptable standards of validity and reliability analyses. Outcomes of stepwise regression analysis confirmed that communication and delivery mode did act as important determinants of training transfer, but support and assignment did not act as important determinants of training transfer in the studied organization. This result partially support training research literature mostly published in overseas. Therefore, current research and practice within training management models needs to consider support, communication, training assignment and delivery mode as important components of the training system where the willingness of top management to properly implement such components in training programs will powerfully push subsequent positive personal outcomes (e.g., satisfaction, commitment, trust, good working ethics and performance). Thus, these positive outcomes may lead to an increased organizational competitiveness in dynamic environments.

\section{References}

1. Abdullah M.M., Baroto M.B., Ismail A., Tat H.H. 2011. Supervisor's role in traning programs as a manager of learning Program, LogForum, 7(2), 2, 1-26

2. Acton T., Golden W., 2003. Training the knowledge worker: a descriptive study of training practices in Irish software companies, Journal of European Industrial Training, 27(2/3/4).

3. Adams J.S., 1963. Towards an understanding of inequity, Journal of Abnormal and Social Psychology, 67, 422-436.

4. Adams J.S., 1965. Inequity in social exchange. In Berkowitz, L, Advances in Experimental Social Psychology, 2, 267-299. 
5. Al-eisa A. S., Furayyan M. A., Alhemoud A. M., 2009. An empirical examination of the effects of self-efficacy, supervisor support and motivation to learn on transfer intention, Management Decision, 47(8), 1221-1244.

6. Arthur, W., Bennett W., Edens P. S., Bell S. T., 2003. Effectiveness of training in organizations: A meta-analysis of design and evaluation features, Journal of Applied Psychology, 83(2), 234245.

7. Assignment, 2000. In The American Heritage Dictionary of the English Language ( $4^{\text {th }}$ ed.), Retrieved from http://www.bartleby.com/61/47/A0474700.html

8. Ayres H. W., 2005. Factors related to motivation to learn and motivation to transfer learning in a nursing population (Doctoral dissertation), Retrieved from http://www.lib.ncsu.edu/theses/available/etd-04052005-204203/unrestricted/etd.pdf

9. Azman I., and Sofiah Bongogoh, 2007. The Supervisor's Role In Training Programmes: An Empirical Study In One City Based Local Authority In Sarawak, Malaysia, UniTAR e-Journal, 3 (2). pp. 60-71. ISSN 1511-7219

10. Baharim S. B., 2008. The influence of knowledge sharing on motivation to transfer training: A Malaysian public sector context (Doctoral dissertation), Retrieved from http://eprints.vu.edu.au/1524/1/Baharim.pdf

11. Bartlett K. R., 2001. The relationship between training and organizational commitment: A study in the health care field. Human Resource Development Quarterly, 12(4), 333-352.

12. Bartlett K. R., Kang D. S., 2004. Training and organizational commitment among nurses following industry and organizational change in New Zealand and United States, Human Resource Development International, 7(4), 423-440.

13. Blanchard P. N., Thacker J. W., 2007. Effective training: Systems, strategies, and practices ( $3^{\text {rd }}$ ed.), Upper Saddle River, NJ: Pearson Prentice Hall.

14. Chang V., 2002. The influence of organizational contextual factors on employee motivation to learn and transfer. (Master Degree Thesis).

15. Chen C. Y., Sok P., Sok K., 2007. Benchmarking potential factors leading to education quality: A study of Cambodian higher education, Quality Assurance in Education, 15(2), 128-148.

16. Cheng E. W. L., Ho D. C. K., 2001. A review of transfer of training studies in the past decade, Personnel Review, 30(1), 102-118.

17. Chiaburu D. S., Marinova S. V., 2005. What predicts skill transfer? An exploratory study of goal orientation, training self-efficacy and organizational supports, International Journal of Training and Development, 9(2), 110-123.

18. Chiaburu D. S., Tekleab A. G., 2005. Individual and contextual influences on multiple dimension of training effectiveness, Journal of European Industrial Training, 29(8), 604-626.

19. Costello A. B., Osborne J. W., 2005. Best practices in exploratory factor analysis: Four recommendation for getting the most from your analysis. Practical Assessment, Research and Evaluation, 10(7), 1-9.

20. Dawley D.D, Andrews M.C, Bucklew N.S, 2008. Mentoring, supervisor support, and perceived organizational support: what matters most?, Journal Leadership \& Organization Development, 29 (3), 235-247.

21. DeSimone R. L., Werner J. M., Harris D. M., 2002. Human resource development. ( $3^{\text {rd }}$ ed.), Mason, OH: Thompson-Southwestern.

22. Eisenberger R., Stinglhamber F., Vandenberghe C., Sucharski I. L., Rhoades L., 2002. Perceived supervisor support: Contributions and perceived organizational support on employee retention, Journal of Applied Psychology, 87(3), 565-573.

23. Ellinger A.E., Ellinger A.D., Keller S.B., 2005. Supervisory coaching in a logistics context, International Journal of Physical Distribution \& Logistics Management, 35 (9), 620-636.

24. Evans D., 2006. Supervisory management: Principles and practice $\left(5^{\text {th }}\right.$ ed.), London, UK: Thomson Learning. 
25. Festner D., Gruber H., 2008. Conditions of work environments in fostering transfer of training. In S. Billet C. Harteis, \& A. Etelapelto (Eds.), Emerging perspectives on learning through work (pp. 215-231), Rotterdam, Netherlands: Sense.

26. Foster D. P., Stine B., Waterman R., 2001. Business analysis using regression: A casebook (Corrected ed.), New York, NY: Springer.

27. Fraenkel J. R., Wallen N. E., 2006. How to design and evaluate research in education $\left(6^{\text {th }}\right.$ ed.), Boston, MA: McGraw-Hill.

28. Furnham A., 2005. The psychology of behaviour at work: The individual in the organization $\left(2^{\text {nd }}\right.$ ed.), New York, NY: Psychology Press.

29. Gagne M., Deci E. L., 2005. Self-determination theory and work motivation, Journal of Organizational Behavior, 26(4), 331-362.

30. Gegenfurtner A., Veermans K., Festner D., Gruber H., 2009. Motivation to transfer training: An integrative literature review, Human Resource Development Review, 8(3), 403-423.

31. Glitten S., 2001. The manager's role in training, Retrieved from http://www.nwsmart.com/ns/getsmart/ARCHIVES/070201.html

32. Goldstein I. L., Ford J. K., 2002. Training in organizations: Needs assessment, development and evaluation $\left(4^{\text {th }}\right.$ ed.), Belmont, CA: Wadsworth Group/ Thomson Learning.

33. Guerrero S., and Sire B., 2001. Motivation to train from the workers' perspectives: Example of French companies, The International Journal of Human Resource Management, 12(6), 9881004.

34. Gumuseli A. I., Ergin B., 2002. The manager's role in enhancing the transfer of training: A Turkish case study, International Journal of Training and Development, 6(2), 80-97.

35. Harris R., Simon M., and J., 2000. More than meets the eye? Rethinking the role of workplace trainer, Australian National Training Authority, 1-65.

36. Holton E. F. III, Bates R., Ruona W. E., 2000. Development of the generalized Learning Transfer System Inventory. Human Resource Development Quarterly, 11(4), 333-360.

37. Hornby A. S., 2005. Oxford Advanced Learner's Dictionary of Current English ( $7^{\text {th }}$ ed.), New York, NY: Oxford University Press.

38. Ismail A., Bakar R. A., Bongogoh S., 2008. Motivation to learn, supervisor's role and transfer of competency: A mediating relationship. Public Service of Malaysia: Journal of Psychology, 3, 89-109.

39. Ismail A., Bongogoh S., 2007. The supervisor's role in training programmes: An empirical study in one city based local authority in Sarawak, Malaysia, Unitar E-Journal, 3(2), 60-71.

40. Ismail A., Bongogoh S., Segaran S. C. C., Tudin R., Ajis M. N., Wan Ismail W. K., 2009. Supervisor communication and motivation to learn as a predictor of positive individual attitudes and behaviours: A study in one city-based local authority, Jurnal Kemanusiaan, 13, 19-29.

41. Ismail A., Khian Jui M.K., Zainal Shah N., 2011a. The Relationship between Gender Type in Mentorship and Mentees' Advancement: An Empirical Study in Malaysia. Theoretical and Applied Economics XVIII, 4 (557), 111-128.

42. Ismail A., Mohamed H.A., Sulaiman A.Z., Sabhi, S., 2010b. Supervisor's Role as an Antecedent of Training Transfer and Motivation to Learn in Training Programs, Acta Universitatis Danubius, 2, 18-38.

43. Ismail A., Segaran S. C. C., Tan C. K., Ong G. L., 2007. Proceeding from AHRDC (Asia Chapter) '07: The mediating role of motivation to learn in the relationship between supervisor's role and job performance.

44. Ismail A, Sieng L.L.C., Abdullah M.M. and Francis, S.K. 2010a. Linking supervisor's role in training programs to motivation to learn as an antecedent of job performance, Intangible Capital, $6(1), 1-25$

45. Ismail A., Sieng L.L.C., Ajis M.N., Dollah N.F., Boerhannoeddin, 2009. Relationship between supervisor's role and job performance in the workplace training program, Analele Stiintifice ale Universitatii "Alexandru Ioan Cuza" din Iasi, 56, 237-251. 
46. Ismail A., Sulaiman A.Z., Mohamed H.A., Mohd Sani, R., 2011b. Procedural Justice As a Moderator in the Relationship between performance Appraisal Communication and job Satisfaction, Revista Negotium, 19(7), 162-186.

47. Kang D., 2007. Perceived organisational justice as a predictor of employees' motivation to participate in training, Research and Practice in Human Resource Management, 15(1), 89-107.

48. Keyton J., 2005. Communication and organizational culture: A key to understanding work experiences, Thousand Oaks, CA: Sage.

49. Klein H. J., Noe R. A., Wang C. W., 2006. Motivation to learn and course outcomes: The impact of delivery mode, learning goal orientation, and perceived barriers and enablers, Personnel Psychology, 59(3), 665-702.

50. Kline P., 2000. The handbook of psychological testing ( $2^{\text {nd }}$ ed.). New York, NY: Routledge.

51. Kothari C. R., 2008. Research methodology: Methods and techniques ( ${ }^{\text {nd }}$ ed.), New Delhi, India: New Age International.

52. Kline P., 2000. The handbook of psychological testing ( $2^{\text {nd }}$ ed.). New York, NY: Routledge.

53. Leedy P.D., Ormrod J.E., 2005. Practical research: Planning and design, Pearson Education Ltd.

54. Lim D.H., 2000. Training design factors influencing transfer of training to the workplace within an international context, Journal of Vocational Education and Training, 52(2), 243-257.

55. Lim D.H., Johnson S.D., 2002. Trainee perceptions of factor that influence learning transfer, International Journal of Training and Development, 6(1), 36-48.

56. Lim D.H., Morris L.M., 2006. Influence of trainee characteristics, instructional satisfaction, and organizational climate on perceived learning and training transfer, Human Resource Development Quarterly, 17(1), 85-115.

57. Locke E. A., Latham G. P., 1990. A theory of goal setting and task performance, Englewood Cliffs. NJ: Prentice Hall.

58. MacNeil M.C., 2004. Exploring the supervisor role as a facilitator of knowledge sharing in teams, Journal of European Industrial Training, 28(1), 93-102.

59. Brooke M., 2005. The Role and Responsibilities of the Supervisor Part 2. Retrieved September 19, 2008 from http://www.articlealley.com/article 19024 36.htm.

60. Machin M. A., 2002. Planning, managing, and optimizing transfer of training, In K. Kraiger (Ed.), Creating, implementing, and managing effective training and development (pp. 263-301), San Francisco: Jossey-Bass.

61. Machin M. A., Fogarty G. J., 2003. Perceptions of training-related factors and personal related variables as predictors of transfer implementation intentions, Journal of Business and Psychology, 18(1), 51-71.

62. Machin M. A., Treloar C. A., 2004. Proceeding from APSAC '04: Predictors of motivation to learn when training is mandatory.

63. Mamat I., 2001. Effective design and successful management of training, Selangor: Eastview.

64. McShane S. L., Von Glinow M. A., 2005. Organizational behaviour: Emerging realities for the workplace revolution ( $3^{\text {th }}$ ed.), New York, NY: McGraw-Hill.

65. Merriam S. B., Leahy B., 2005. Learning transfer: A review of the research in adult education and training, Journal of Lifelong Learning, 14, 1-24.

66. Nijman D. J. J. M, Wognum W. J. N., Veldkamp B. P., 2006. Exploring differential effects of supervisor support on transfer of training, Journal of European Industrial Training, 30(7), 529549.

67. Nijman D.J., 2004. Supporting transfer of training. Effect of the supervisor. Doctoral Dissertation, Enschede The Netherland: University of Twente.

68. Nijman, D.J. Nijhof W.J., Wognum A.A.M., Veldkamp B.P., 2008. Exploring differential effects of supervisor support on transfer of training. Journal of European Industrial Training, 30(7), 529-549.

69. Ng C. H., Bahr N., 2000. Knowledge structure and motivation to learn: Reciprocal effects, Queensland Journal of Educational Research, 16(1), 76-106. 
70. Ng, T. W. H., Eby L. T., Sorensen K. L., Fledman D. C., 2005. Predictors of objective and subjective career success: A meta-analysis, Personnel Psychology, 58(2), 367-408.

71. Noe R.A., 2005. Employee training and development. Boston, McGraw Hill.

72. Orvis K. A., Horn D. B., Belanich J., 2006. Video-game based training success: The impact of trainee characteristics-Year 2., United States Army Research Institute for the Behavioral Social Sciences, 1-38.

73. Robbins S.P., DeCenzo D.A., 2004. Supervision today. USA: Pearson Prentice Hall.

74. Robbins S. P., Coulter M., 2005. Management ( $8^{\text {th }}$ ed.), Upper Saddle River, NJ: Pearson Education.

75. Robbins S. P., DeCenzo D. A., 2006. Supervision today (5 $5^{\text {th }}$ ed.), USA: Prentice Hall.

76. Rodrígues C.M., Gregory S., 2005. Qualitative study of transfer of training of student employees in a service industry, Journal of Hospitality and Tourism Research, 29(1), 42-66.

77. Saks A. M., Belcourt M., 2006. An investigation of training activities and transfer of training in organizations, Human Resource Management, 45(4), 629-648.

78. Sekaran U., 2000. Research methods for business: A skill building approach. NewYork: John Wiley \& Sins, Inc.

79. Sekaran U., 2002. Research methods for business: A skill building approach (4 ${ }^{\text {th }}$ ed.). Hoboken, NJ: John Wiley \& Sons.

80. Sisson G. R., 2001. Hands-on-training: A simple and effectiveness method of on-the-Job training, San Francisco, CA: Berret-Koehler.

81. Smith-Jentsch K. A., Salas E., Brannick M. T. 2001. To transfer or not to transfer? Investigating the combined effects of trainee characteristics, team leader support, and team climate, Journal of Applied Psychology, 86(2), 279 -292.

82. Stansfield T. C., Longenecker C. O., 2006. The effects of goal setting and feedback on manufacturing productivity: A field experiment. International Journal of Productivity and Performance Management, 55(3/4) 346-358.

83. Subedi B. S., 2004. Emerging trends of research on transfer of learning, International Journal 5(4), 591-599.

84. Switzer K. C., Nagy M. S., Mullins M. E., 2005. The influence of training reputation, managerial support, and self-efficacy on pre-training motivation and perceived training transfer, Applied H.R.M. Research, 10(1), 21-34.

85. Tsai W.C., Tai W.T., 2003. Perceived importance as a mediator of the relationship between training assignment and training motivation, Personal Review, 31(2), 151-163

86. Van Teijlingen E. R., Hundley V., 2001. Social research update: The importance of pilot studies. Guildford, UK: University of Surrey.

87. Velada R., Caetano A., 2007. Training transfer: The mediating role of perception of learning. Journal of European Industrial Learning, 31(4), 283-296.

88. Velada R., Caetano A., Michel J. W., Lyons B. D., Kavanagh M. J., 2007. The effects of training design, individual characteristics and work envirnronment on transfer of training, International Journal of Training and Development, 11(4), 282-294.

89. Vroom V.H., 1964. Work and motivation, New York: John Wiley \& Sons.

90. Vuuren M.V, de Jong M.D.T, Seydel E.R., 2007. Direct and indirect effects of supervisor communication on organizational commitment, International Journal, 12 (2), 116-128.

91. Wexley K. N., Latham G. P., 2001. Developing and training human resources in organizations $\left(3^{\text {rd }}\right.$ ed.), New York, NY: HarperCollins.

92. Yamnill S., McLean G. N., 2001. Theories supporting transfer of training. Human Resource Development Quarterly, 12(2), 195-208.

93. Zikmund W. G., 2000. Business research methods (6 $6^{\text {th }}$ ed.), Fort Worth, TX: The Dryden Press. 